\title{
CALCULATION OF ROLLING FORCE IN THE HOT STRIP FINISHING MILL USING AN EMPIRICAL MODEL
}

\author{
Antonio Adel dos Santos ' \\ Jônatas Venâncio Barbosa ${ }^{2}$
}

\begin{abstract}
Mathematical models for rolling force calculation during hot rolling are crucial for both automatic mill operation and prediction of steel behavior and mill capacity, especially for development of new steel grades and improvement of the existing ones. In literature, the models are based usually on the calculation of steel mean flow stress (MFS), firstly, followed by a force model based on MFS. This approach was applied to a large volume of industrial data of coils produced at Usiminas' plant in Ipatinga, giving unsatisfactory results. Then, the empirical model developed by Schultz was applied to calculate directly the force, with further fine tuning the model with a linear regression taking into account the steel chemical composition. This approach led to a force prediction capability better than the traditional models based on the binomial MFS-force presented in literature, markedly for plain CMn and IF steels. In such cases, more than $90 \%$ of force predictions were inside the $\pm 10 \%$ error margin, considering the front stands of the hot strip mill.
\end{abstract}

Keywords: Hot strip mill; Rolling force; Mean flow stress; Schultz model.

\section{INTRODUCTION}

One fundamental requirement for fully automatic operation of hot strip mills is the calculation of rolling force in each rolling stand by mathematical models. There are several approaches and mathematical formulae proposed in literature [I,2], each one having its particularities, advantages and disadvantages. The accuracy and precision levels achieved by those models depend also on specific features of each hot strip mill line.

The most common way to calculate rolling force reported in literature is given by Equation I, based on the concept of force as given by the product of material mean flow stress by the contact area. There is still a multiplying geometric factor, which takes into account tribological features between rolling rolls and material being rolled. That well known expression was developed by Sims [3], where $F$ is the rolling force; $Q_{p}$, the geometric factor; $w$, strip width; $L_{d}$, length of contact arc and MFS, the steel mean flow stress.

$$
F=Q_{p} \cdot M F S \cdot w \cdot L_{d}
$$

In such approach, the MFS becomes a key factor to be determined in order to calculate rolling force with the required precision. Several papers in literature [4-6] have presented contributions to improve MFS prediction, notably in hot strip mills, including those related to Usiminas' plant $[7,8]$. Nevertheless, the accomplished advances in this field have not allowed yet the establishment of generalized equations to predict MFS in hot rolled steels, as a function of steel chemistry, strain, temperature and strain rate, during the rolling passes.

This paper shows an alternative methodology for direct calculation of rolling force by using the empirical equation proposed by Schultz [9]. The obtained results for Usiminas' hot strip mill in Ipatinga outperformed those achieved by the traditional approach based on the binomial MFS-Force.

\section{METHODOLOGY}

The processing data of 36742 coils produced from May to July, 2017 were collected. The data were the following: chemical composition and steel family; strip width and end thickness; temperature, strain, strain rate, entry and exit strip thicknesses, work roll radius and force, for each rolling stand.

Based on the expected metallurgical behavior of the steels, together with their chemistries, the total set of coils was split in nine groups. Out of those groups, four were selected in this paper to be shown as application examples of the methodology: CMn aluminum killed steels, $\mathrm{Nb}$ microalloyed steels, IF steels and high-silicon steels.

\section{I Attempt to Model MFS}

Misaka's equation, given by (2), was used for calculating MFS in each rolling stand. $\mathrm{fCT}_{\text {Mis }}$ means a function of steel carbon content and deformation pass temperature, according

'Centro de Pesquisa e Desenvolvimento, Usiminas, Ipatinga, MG, Brasil.E-mail: antonio.adel@usiminas.com

¿Unidade Técnica da Laminação a Quente, Usiminas, Ipatinga, MG, Brasil.

2176-I523 (C) 2020. Santos et al. Published by ABM. This is an Open Access article distributed under the terms of the Creative Commons Attribution License, which permits unrestricted use, distribution, and reproduction in any medium, provided the original work is properly cited. 
to Equation 3, where MFS $S_{\text {Mis }}$ is calculated by Misaka (MPa); $\varepsilon$, is the strain $(\mathrm{mm} / \mathrm{mm}) ; \dot{\varepsilon}$, strain rate $\left(\mathrm{s}^{-1}\right)$; C: carbon content (\% mass) and $\mathrm{T}$ is pass temperature $\left({ }^{\circ} \mathrm{C}\right)$.

$$
\begin{aligned}
& M F S_{\text {Mis }}=9.8 \exp \left(f C T_{M i s}\right) \varepsilon^{0.21} \dot{\varepsilon}^{0.13} \\
& f C T_{M i s}=0.126-1.75 C+0.594 C^{2}+\frac{2851+2968 C-1120 C^{2}}{T}
\end{aligned}
$$

Providing that the Sims model given by Equation I be correct for rolling force calculation and that such force is measured, the actual MFS, called MFS $_{\text {sims }}$, was calculated by inverting that equation.

In this work, following the literature [2,10], it was shown that the original $\mathrm{MFS}_{\text {Mis }}$ needs to be adjusted in order to predict MFS $_{\text {Sims }}$ properly. It was also noticed in this work by preliminary analyses that the exponential shapes $\varepsilon^{0.21}$ and $\dot{\varepsilon}^{0.13}$ reflected quite well the effects of strain and strain rate, respectively, on MFS.

Hence, it was tried to fit the parameter $\mathrm{fCT}_{\text {Mis }}$ by comparing it with the so called actual $\mathrm{fCT}_{\text {sims }}$, given by Equation 4. In order to fit $\mathrm{fCT}_{\text {Mis }}$ several types of equations employing linear, polynomial and exponential expressions as a function of steel chemistry and deformation temperature were tried.

$$
f C T_{\text {Sims }}=\ln \left(M F S_{\text {Sims }}\right)-\ln (9.8)-0.21 \ln (\varepsilon)-0.13 \ln (\dot{\varepsilon})
$$

\subsection{Direct Calculation of Rolling Force}

Since the failure in attempting to model the MFS with the aimed accuracy, it was resorted to the Schultz's equation as given by (5) for direct calculation of rolling force. This equation was developed from measurements carried out during experimental hot rolling in a reversing pilot mill, but the author reported neither the rolling conditions nor the steel chemistry ranges used. The variables are: F, rolling force $\left(t_{f}\right) ; b_{0}$ to $b_{7}$, constants to be determined by multiple linear regressions; $R$, average work roll radius $(m) ; h_{1}$, entry thickness $(\mathrm{m}) ; \Delta \mathrm{h}$, thickness reduction $(\mathrm{m}) ; \mathrm{T}$, deformation temperature $\left({ }^{\circ} \mathrm{C}\right) ; \mathrm{w}$, strip width $(\mathrm{m})$.

$$
\begin{aligned}
& \ln F=b_{0}+b_{1} \ln \left(\frac{R}{h_{1}}\right)+b_{2} \ln \left(\frac{\Delta h}{h_{1}}\right)+b_{3} \ln \left(\frac{R}{h_{1}}\right) \ln \left(\frac{\Delta h}{h_{1}}\right)+ \\
& b_{4} \frac{T}{1000}+b_{5} \frac{T}{1000} \ln \left(\frac{\Delta h}{h_{1}}\right)+b_{6} \ln \left(\frac{\Delta h}{h_{1}}\right) \ln \left(\frac{R}{h_{1}}\right)^{2}+ \\
& b_{7}\left(\frac{T}{1000}\right)^{2}+\ln (w)+\frac{1}{2}[\ln (R)+\ln (\Delta h)]
\end{aligned}
$$

Good prediction of rolling force was achieved through Equation 5, which was further tuned by a multiplying factor given by a linear regression as a function of steel chemical composition according to Equation 6, where: $\mathrm{F}_{\text {Calc }}$, corrected rolling force (tf); $a_{o}, a_{i}$, constants to be determined by multiple linear regression; $E_{i}, \%$ mass content of chemical element $i$; $\mathrm{n}$, number of chemical elements used for tuning.

$$
F_{\text {Calc }}=F\left(a_{0}+\sum_{l}^{n} a_{i} E_{i}\right)
$$

\subsection{Analysis of MFS Behavior}

The corrected MFS named MFS Cor' $_{\text {, Equation 7, was }}$ used to analyze the softening and hardening behaviors of each steel family, and help explain the prediction errors provided by Schultz's model. The correction by 0.40 strain and $40 \mathrm{~s}^{-1}$ strain rate was used to isolate the temperature effect on MFS.

$$
M F S_{\text {Cor }}=M F S_{\text {Sims }}\left(\frac{0.40}{\varepsilon}\right)^{0.21}\left(\frac{40}{\dot{\varepsilon}}\right)^{0.13}
$$

In addition, MicroSim software [ $\mathrm{I}$ ] was used to simulate the microstructural evolution for $\mathrm{Nb}$ microalloyed steels, aiming at understanding, with the help of MFS ${ }_{\text {Cor }}$ the errors associated to the Schultz's equation.

\section{RESULTS AND DISCUSSION}

\section{I Force Calculation Through MFS}

Figures Ia and $\mathrm{I} b$ show plots of $\mathrm{fCT}_{\text {Mis }}$ versus $\mathrm{fCT}_{\text {Sims }}$ in stands $\mathrm{FI}$ and $\mathrm{F} 4$ for the $\mathrm{CMn}$ steel family, as examples of the analyses carried out for all stands. The graphs point out that the range of $\mathrm{fCT}_{\text {Mis }}$ was too narrow, thus preventing $M \mathrm{SS}_{\text {Mis }}$ from matching the wide range of $\mathrm{MFS}_{\text {Sims }}$ needed for the actual MFS. In other words, the variations of $C$ content and temperature applied in Equation 3 are insufficient to provide the required variation in $\mathrm{fCT}_{\text {Mis }}$. The difference in fCT ranges increases from stand $\mathrm{FI}$ to $\mathrm{F} 6$, that is, the error is amplified from front to rear stands.

Figures Ic and Id show plots of $\mathrm{fCT}_{\text {Mis-cor }}$ versus $\mathrm{fCT}_{\text {Sims. }}$. $\mathrm{fCT}_{\text {Mis-cor }}$ values were obtained by applying the correction to $\mathrm{fCT}_{\text {Mis }}$ using a linear regression taking into account $\mathrm{C}$ and $\mathrm{Mn}$ contents in steel. Despite a remarkable improvement in $\mathrm{fCT}$ predictability, there is still a large scattering, which can be evaluated by the determination coefficient, $\mathrm{r}^{2}$, in the range 0.65 to 0.68 .

The recalculation of MFS by Equation 2 applying $\mathrm{fCT}_{\text {Mis-cor }}$ led to the graphs shown in Figures le and If, for stands FI and F4, respectively. The results were not satisfactory from the standpoint of force calculation with the required precision, as the scattering in calculated MFS was too large. Attempts to improve the correction of $\mathrm{fCT}_{\text {Mis }}$ by using different regression equations like exponentials and polynomials did not succeed.

The previous analysis was applied to the IF steels family, whose $\mathrm{C}$ content lies below 35 ppm, having potential additions of $\mathrm{Nb}, \mathrm{Ti}$ and $\mathrm{B}$. The results were even less promising than for $\mathrm{CMn}$ steels, when considering the methodology to fit fCT as a function of temperature and chemical composition. Figures $2 \mathrm{a}$ and $2 \mathrm{~b}$ show the graphs of 

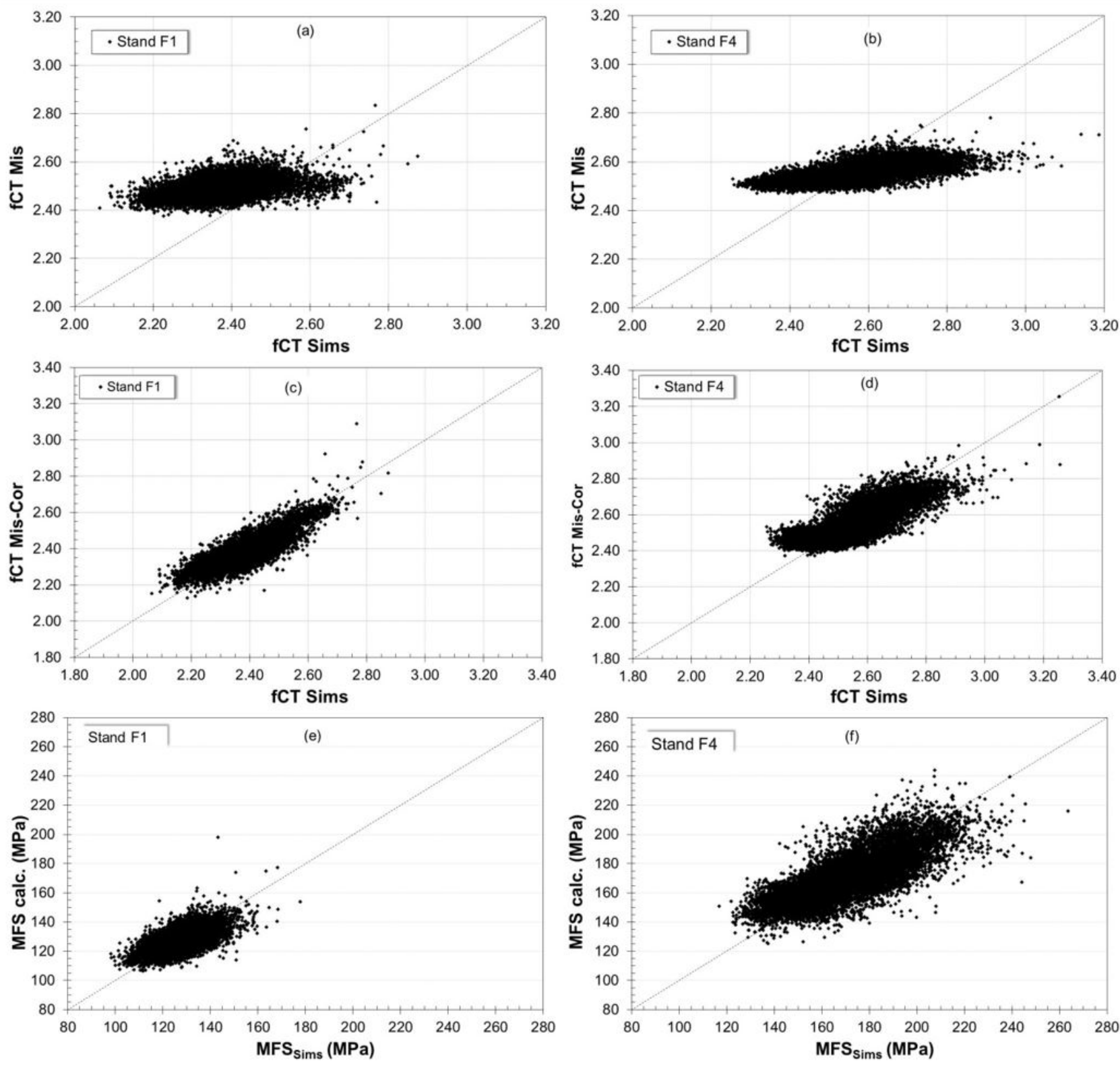

Figure I. Plots of $\mathrm{fCT}$ and MFS in FI and F4 stands for CMn aluminum killed steels.
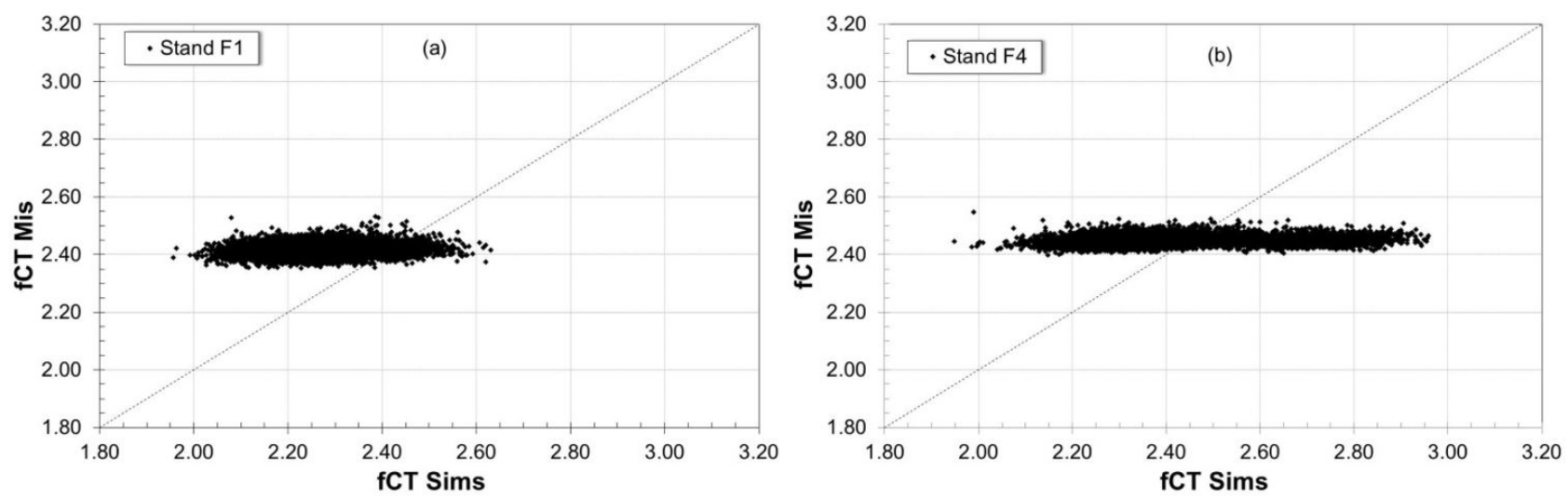

Figure 2. Plots of fCT in FI and F4 stands for IF steels. 
$\mathrm{fCT}_{\text {Mis }}$ versus $\mathrm{fCT}_{\text {Sims }}$ for IF steels. The narrow variations of $\mathrm{C}$ content and deformation temperature in each stand did not allow large variations in $\mathrm{fCT}_{\text {Mis }}$ which would correspond to the wide range of $\mathrm{fCT}_{\text {Sims }}$. Even after correcting $\mathrm{fCT}_{\text {Mis }}$ by linear regressions as a function of steel alloying elements, the fitting results were poor.

Therefore, the methodology of fitting MFS $_{\text {Mis }}$ was considered inappropriate in this work to achieve the proposed aim of establishing an accurate model for rolling force.

\subsection{Direct Calculation of Force}

\subsection{CMn steels}

The number of coils belonging to this steel family amounted 13620, with the following chemistry ranges: C: $0.01 \% \sim 0.23 \%$; Mn: 0.12\% I.66\%; B < 0.0040\%. Schultz's model was applied to each rolling stand giving a good fit to experimental data. There was a general trend of worsening the fit from front to rear stands, especially in F4 and F6. The best fit in stand FI is expected because the steel microstructure is usually fully recrystallized, relatively homogeneous and there is neither effect of bending nor backwards tension. It should be noted the Schultz's model was developed based on data of reversing mill, where those effects are absent.

Figure 3 shows, as an example, plots of calculated versus measured rolling forces in stands $\mathrm{FI}$ and $\mathrm{F6}$, which had
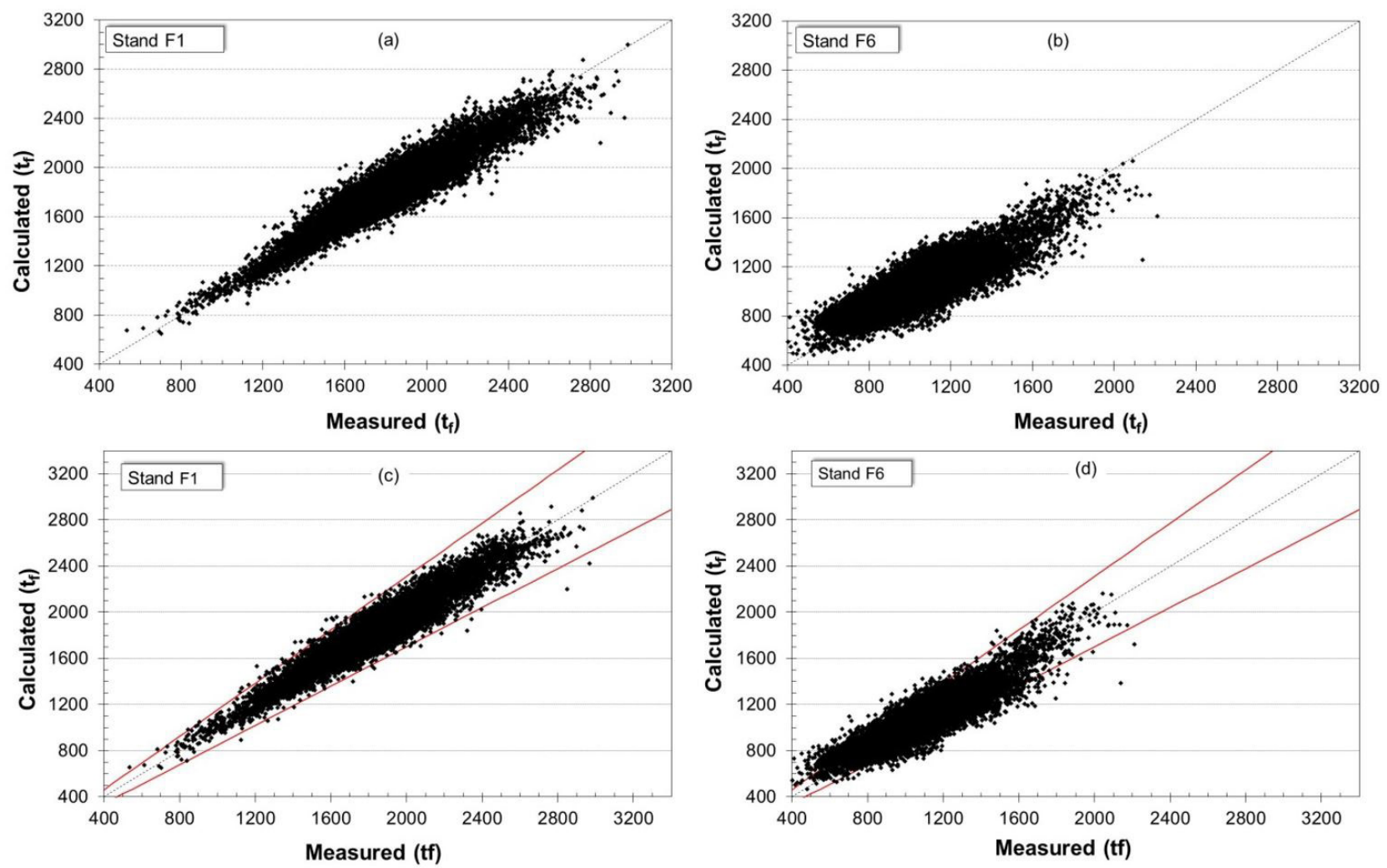

the best and worst fit, respectively. In Figures $3 \mathrm{a}$ and $3 \mathrm{~b}$ the calculated values are those obtained with direct application of the Schultz's equation. In Figures $3 c$ and $3 d$ the calculated values refer to the corrected ones taking into account the chemical composition by Equation 6. In this case, the coefficients $\mathrm{a}_{1}, \mathrm{a}_{2}$ and $\mathrm{a}_{3}$ correspond to $\mathrm{C}, \mathrm{Mn}$ and $\mathrm{B}$ contents. It can be noticed a slight improvement of prediction power after the correction, as the determination coefficient, $r^{2}$, kept above 0.90 in the first three stands. Almost all values are within the $\pm 15 \%$ error limits.

Table I shows the fitting coefficients used for correcting the force calculation in function of chemical composition, Equation 6. It shows also the error analysis in stands FI and F6. Such analysis shows the percentage of calculated values that are within the error margin of $\pm 10 \%$, which is an appropriate measure to evaluate any rolling force model accuracy, according to Gorni and Silva [2]. These authors evaluated the power of several models, based on the approach MFS-Force, to predict the rolling force of $\mathrm{CMn}$ in $\mathrm{FI}$ stand. The combined MFS-Force model that best performed reached $88 \%$ outcomes within the $\pm 10 \%$ error margin, while another author [12] reported a hit rate of maximum $87 \%$ within this error margin, for $\mathrm{CMn}$ as well. In the first three stands the present corrected Shcultz's model overcome these best references in literature, thus having high potential to be applied to industrial process.

In addition, the positive values of the fitting parameters $a_{1}, a_{2}$ and $a_{3}$ indicate higher rolling force as $C, M n$ and $B$

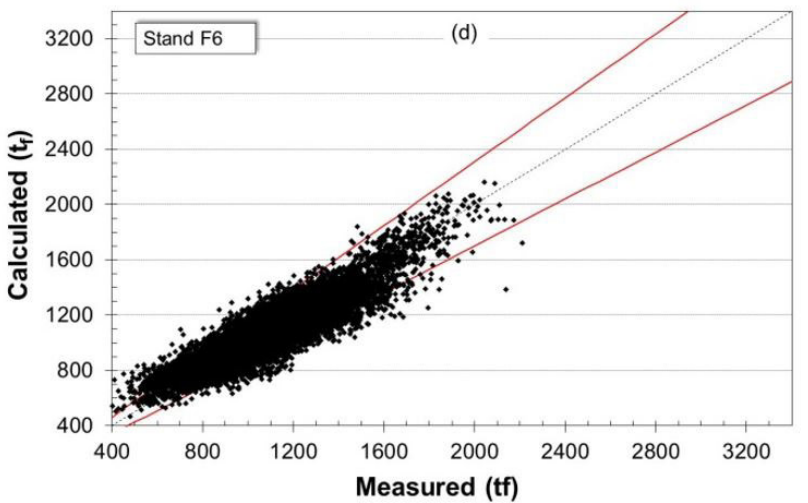

Figure 3. Comparison between calculated and measured force in FI and F6 stands for CMn steels. (a) and (b), without correction; (c) and (d) after correction. Red lines in (c) and (d) denote error margin of $\pm 15 \%$. 
contents increase. This is expected due to their solid solution strengthening effect according to the literature [10].

\subsubsection{Nb microalloyed steels}

There were 6354 coils of $\mathrm{Nb}$ microallyed steels, which had additions of $\mathrm{Nb}$ always, Ti, very often, and $\mathrm{V}$, hardly, but no additions of alloyings such as $\mathrm{Cr}$ and Mo. The chemical composition ranges were: C: $0.001 \% \sim 0.172 \%$; Mn: $0.08 \% \sim 1.64 \% ; \mathrm{Nb}<0.068 \% ; \mathrm{Ti}<0.033 \%$; $\mathrm{V}<0.052 \%$.

The application of the Schultz's model led to reasonable prediction capability of rolling forces, as shown by the graphs in Figures $4 \mathrm{a}$ and $4 \mathrm{~b}$, in stands $\mathrm{FI}$ and $\mathrm{F} 4$, respectively. The determination coefficient, $r^{2}$, varied from 0.64 in stand F6 to 0.86 in stand FI. The fit was worse than for CMn steels, as expected, since $\mathrm{Nb}$ may precipitate with $\mathrm{C}$ and $\mathrm{N}$ during hot rolling causing additional hardening of austenite due to the suppression of static recrystallization (SRX).

$\mathrm{C}, \mathrm{Mn}$ and $\mathrm{Nb}$ are the elements that cause the highest hardening effect in such microalloyed steels, in addition to
Ti and V. Therefore, they all were included in the linear regression equation for correcting the original force calculation by Schultz. The graphs of calculated versus measured force in Figures 4c and 4d show a slightly better model accuracy after the correction by steel chemistry.

Table 2 shows the fitting parameters for force calculation model as a function of steel chemistry, together with the determination coefficient and the hit rate within the different established error ranges, in FI and F4 stands. The coefficients $a_{1}$ to $a_{5}$ are associated to $C, M n, N b, T i$ and $\mathrm{V}$, in this order. The hit rate within $\pm 10 \%$ error margin changes from $65 \%$ in F4 stand to $89 \%$ in FI stand. The $89 \%$ value overcomes the best result reported by Gorni and Silva [2], whereas in the other stands the hit rate remains below the referenced value. Thus, the model here presented may be useful for force prediction, especially when the FI value only is searched.

In a search for explaining the force estimation error in all stands, MFS $_{\text {Cor }}$ curves as a function of temperature were drawn, as shown in Figure 5. Subsets of coils were generated according to the error margin of force calculation

Table I. Fitting parameters obtained by linear regression in Equation 6 and model hit percentage in FI and F6 stands for CMn steels

\begin{tabular}{|c|c|c|c|c|c|c|c|c|}
\hline \multirow{2}{*}{ Stand } & \multicolumn{5}{|c|}{ Fitting parameters - Equation 6} & \multicolumn{3}{|c|}{ Model hit rate } \\
\hline & $a_{0}$ & $a_{1}$ & $a_{2}$ & $a_{3}$ & $\mathbf{r}^{2}$ & $>+10 \%$ & $<-10 \%$ & $-10 \% \sim 10 \%$ \\
\hline $\mathrm{FI}$ & 0.947 & 0.462 & 0.028 & 10.321 & 0.91 & 2.6 & 1.7 & 95.7 \\
\hline F6 & 0.862 & 1.227 & 0.052 & 45.498 & 0.82 & 14.8 & 14.2 & 71.1 \\
\hline
\end{tabular}

$a_{0}, a_{1}, a_{2}, a_{3}$ são coeficientes de ajuste; $r^{2}$ é o coeficiente de determinação.
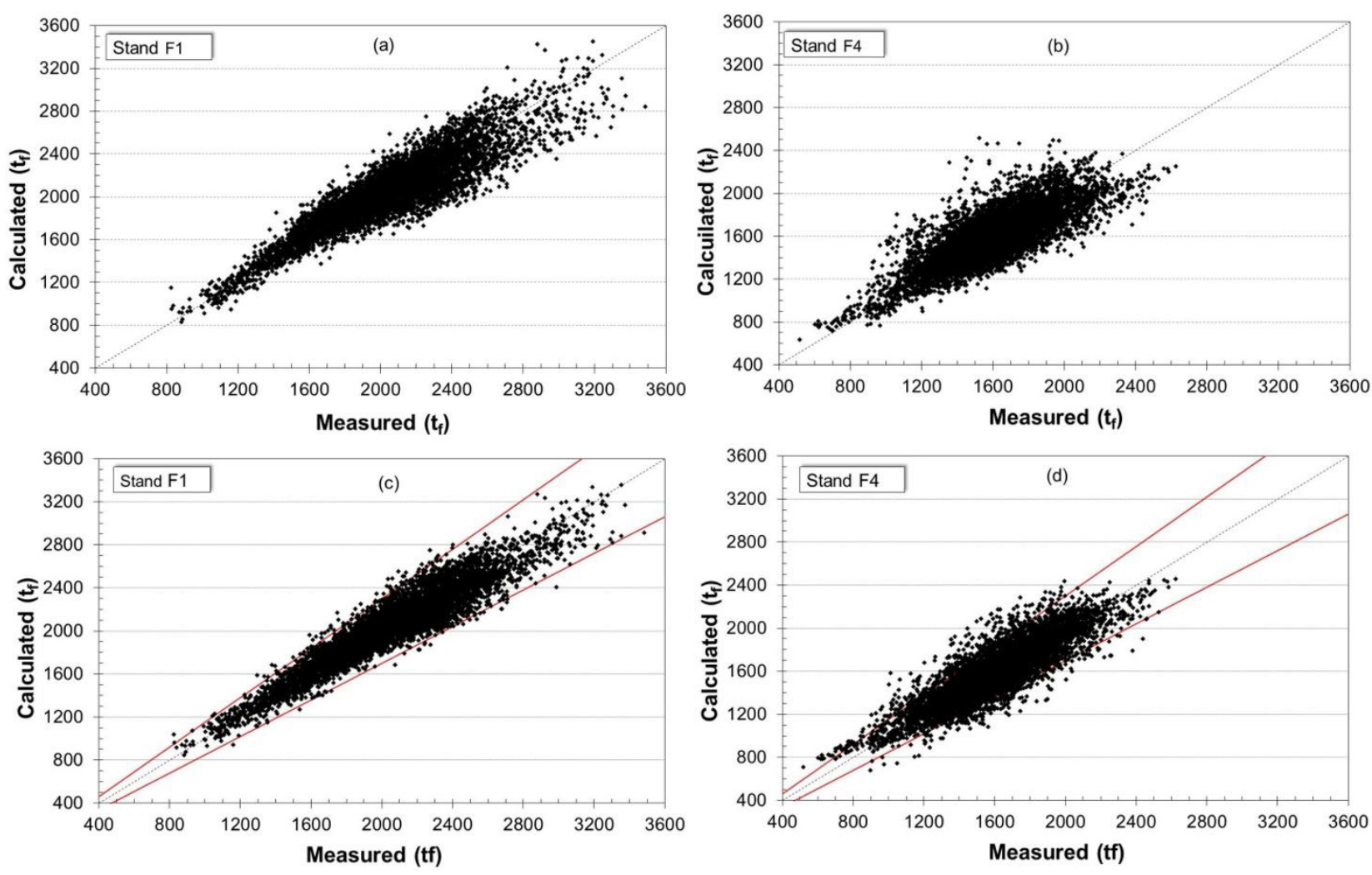

Figure 4. Calculated and measured force in FI and F4 stands for Nb microalloyed steels. (a) and (b), without correction; (c) and (d) after correction. 
Table 2. Fitting parameters obtained by linear regression in Equation 6 and model hit percentage in $\mathrm{FI}$ and $\mathrm{F} 6$ stands for Nb microalloyed steels

\begin{tabular}{|c|c|c|c|c|c|c|c|c|c|c|}
\hline \multirow{2}{*}{ Stand } & \multicolumn{7}{|c|}{ Fitting parameters - Equation 6} & \multicolumn{3}{|c|}{ Model hit percentage } \\
\hline & $a_{0}$ & $\mathbf{a}_{1}$ & $a_{2}$ & $a_{3}$ & $\mathbf{a}_{4}$ & $a_{5}$ & $\mathbf{r}^{2}$ & $>+10 \%$ & $<-10 \%$ & $-10 \%$ to $+10 \%$ \\
\hline $\mathrm{FI}$ & 0.848 & 0.256 & 0.106 & 1.307 & -3.176 & 1.822 & 0.88 & 6.3 & 4.3 & 89.3 \\
\hline $\mathrm{F} 4$ & 0.733 & 0.876 & 0.098 & 3.287 & -2.016 & 1.394 & 0.72 & 18.7 & 16.4 & 64.9 \\
\hline
\end{tabular}

$a_{0}, a_{1}, a_{2}, a_{3}, a_{4}, a_{5}$ são coeficientes de ajuste; $r^{2}$ é o coeficiente de determinação.

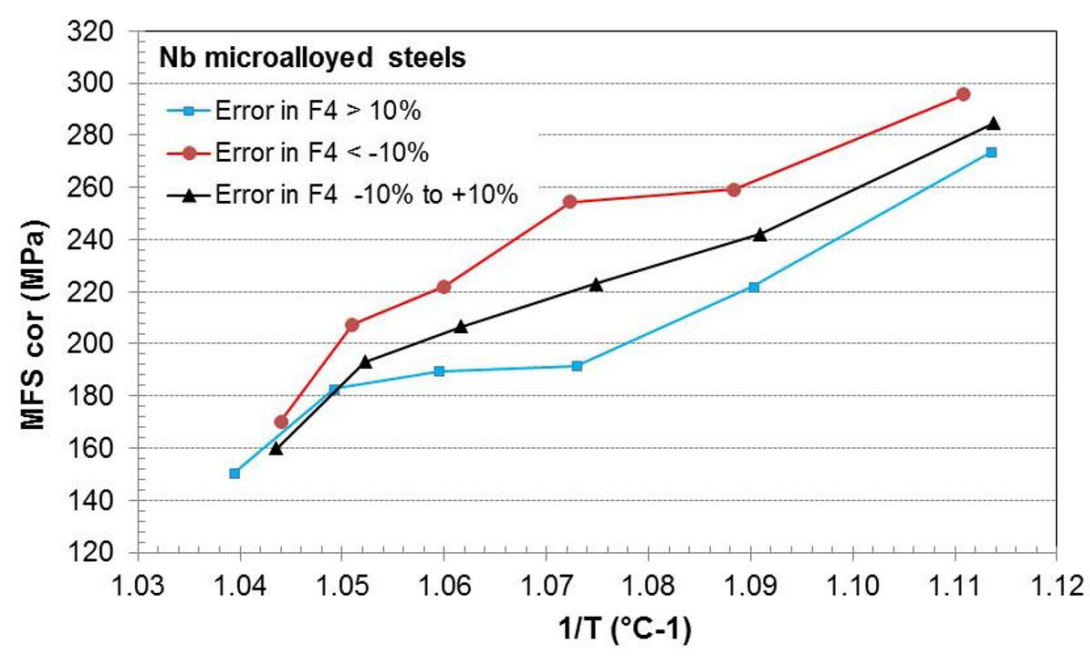

Figure 5. Evolution of MFS for $\mathrm{Nb}$ microalloyed steels.

Table 3. Average element content (\%mass/mass) in the subsets of coils with different rolling force error margin in stand F4

\begin{tabular}{ccccc}
\hline Error range in F4 & C & Mn & Si & Nb \\
\hline Error $<-10 \%$ & 0.092 & 1.241 & 0.119 & 0.036 \\
$-10 \%<$ error $<10 \%$ & 0.079 & 0.964 & 0.058 & 0.033 \\
Error $>+10 \%$ & 0.070 & 0.720 & 0.026 & 0.027 \\
\hline
\end{tabular}

in $\mathrm{F} 4$, that is: error greater than $+10 \%$, error between $-10 \%$ and $+10 \%$, and error below $-10 \%$. Stand F4 was chosen because it presented the largest spread in errors.

The MFS level is higher in microalloyed steels than in $\mathrm{CMn}$ steels, achieving values from $270 \mathrm{MPa}$ to $300 \mathrm{MPa}$ in F6. In general, the MFS curves present a roughly constant slope along with temperature decrease. In stand F3, the MFS achieves $200 \mathrm{MPa}$, meaning absence of significant austenite SRX from this stand on, according to Stalheim [13].

When considering the underestimated data of rolling force, that is, error $<-10 \%$, it can be noticed that their behavior is different from the data with error $>+10 \%$. In the latter, the MFS keeps almost the same level in stands F2 to F4, implying that the strain hardening during the deformation is being cancelled by the softening mechanisms between passes. On the other hand, in the coils having error $<-10 \%$ the MFS always increases between stands, especially from F3 to F4.

Obviously this is in part due to the very concept of data split. In addition, it was found that the C, Mn and $\mathrm{Nb}$ contents differed among each subset of data, as given by Table 3. The effect of C, Mn and $\mathrm{Nb}$ on increasing rolling force was found by the positive values of the fitting parameters in Table 2, as expected.
The MicroSim model was applied to realize the microstructure evolution regarding two subsets of coils: those with error $>+10 \%$ and those with error $<-10 \%$. Figure 6 shows the predicted static recrystallized fraction for both subsets of coils.

During rough rolling full SRX takes place between deformation passes. During finishing rolling, once the strip goes through $\mathrm{FI}$ stand SRX is delayed, so that the material is only partially recrystallized. In the subset of coils with error $>+10 \%$ partial SRX takes place from FI to F5, being nearly suppressed in F6. In the other subset the delay in $\mathrm{SRX}$ is much longer, and from FI stand on it is no more appreciable, because of solute drag and precipitate pinning effects. This finding corroborates the increase in MFS in this subset of coils, see Figure 6, that, in turn, will cause higher rolling force. Such behavior is also associated to a higher level of $\mathrm{C}, \mathrm{Mn}$ and $\mathrm{Nb}$ as shown in Table 3. The effect of chemistry on SRX kinetics is nonlinear, so it would not be expected a very good adjustment of the calculated rolling force with the Schultz's model by using the linear correction given in Equation 6. Coupling microstructure and force models would be a suggestion to get even more efficient models for rolling force of $\mathrm{Nb}$ microalloyed steels, especially in rear stands of finishing mill. 
(a)

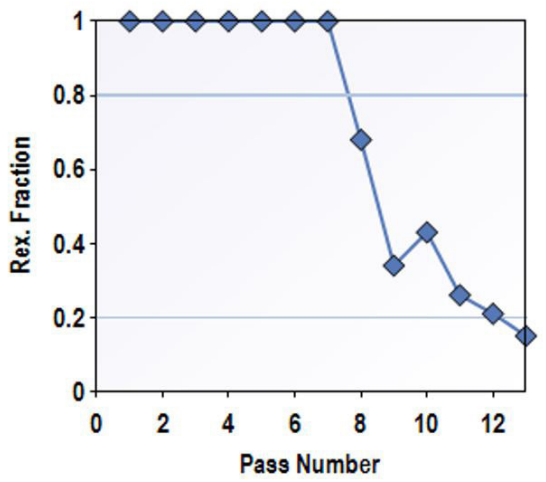

(b)

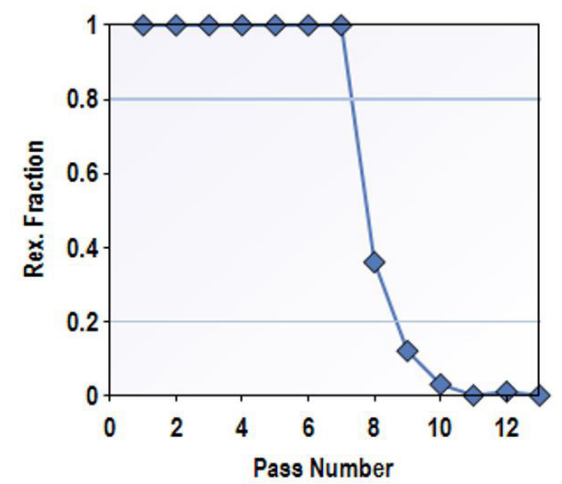

Figure 6. Predicted SRX fraction along the rolling pass sequence for $\mathrm{Nb}$ microalloyed steels, considering the subsets of coils with different error of rolling force calculation in stand F4. (a) Error in stand F4 <-10\%; (b) Error in stand F4 > + $10 \%$.
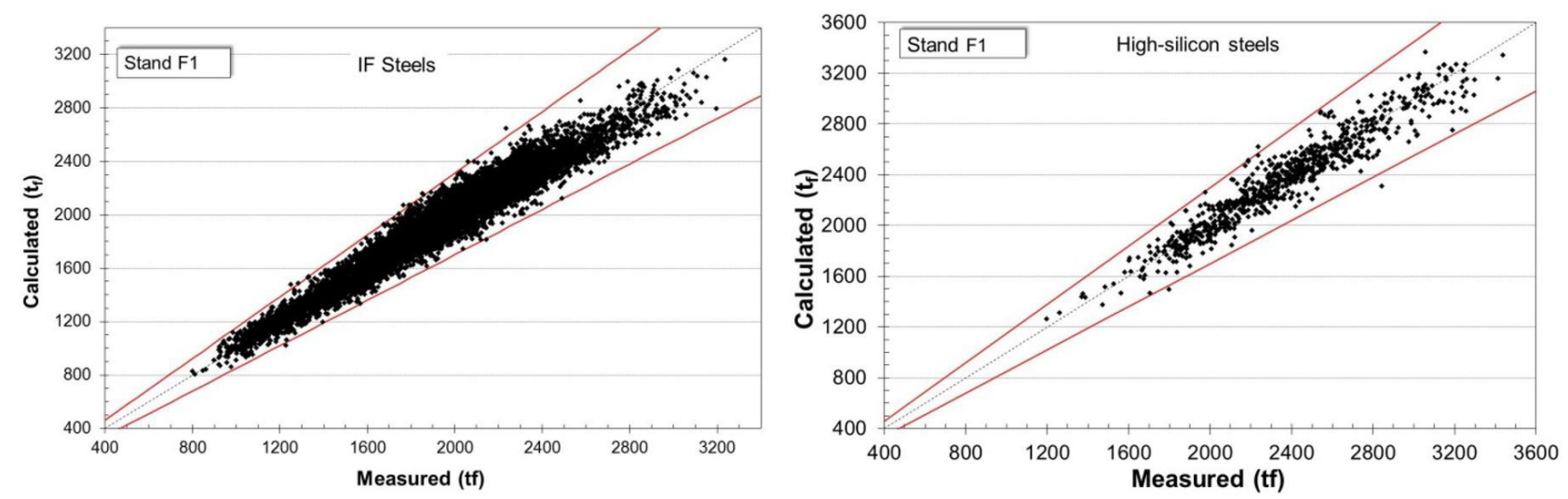

Figure 7. Comparison between calculated and measured rolling force in stand FI for IF and high-silicon steels.

\subsubsection{IF steels and high-silicon steels}

Briefly, the results of rolling force predictions using the Schultz's model are presented for IF and high-silicon steels, emphasizing its suitability for all steel families. There were III 190 coils of IF steels, their composition being as follows. C $\leq 35 \mathrm{ppm}$; Mn: from $0.04 \%$ to $1.6 \%$; $\mathrm{Nb} \leq 0.027 \%$ and $\mathrm{Ti} \leq 0.075 \%$. There were $8 \mathrm{I} 5$ coils of steel classified as high-silicon, whose chemical composition range was: $\mathrm{C}$ between $0.03 \%$ and $0.25 \%$; $\mathrm{Nb} \leq 0.025 \%$; $\mathrm{Mn}$ between $0.21 \%$ and $2.28 \% ; \mathrm{Ti} \leq 0.024 \%$ and $\mathrm{Si}$ from $0.46 \%$ to $1.46 \%$.

Figure 7 shows plots of calculated versus measured force, in stand FI, using the fitted Shcultz's equation after the tuning by steel chemistry. Very good correlations were obtained, the $r^{2}$ coefficient reaching 0.94 and $0.9 \mathrm{I}$ for IF and high-silicon steels, respectively. As a result, the percentage of calculated force values within the error margin of $\pm 10 \%$ was $97 \%$ and $96 \%$, respectively.

\section{CONCLUSION}

Attempts were made to model the rolling force in Usiminas' hot strip mill through the traditional way of modeling the MFS calculated by Misaka's equation, employing modifications according to both proposals in literature and to fitting its exponential term related to temperature and chemical composition. Such approach was inappropriate to achieve the proposed goal in this work.

The equation proposed by Schultz for direct rolling force calculation was applied, thus outperforming the approach of force calculation via MFS. Predictions by the model were further improved by applying corrections with multiple linear regression equations as a function of steel chemical composition.

The best fitting results were obtained by plain CMn, high-silicon and IF steels. As alloying and microalloying elements are added to steel the fitting results worsen. In rear stands, markedly in F4 and F6 the prediction of rolling force worsens further.

For plain CMn, high-silicon and IF steels the proposed model based on the Schultz's equation led to force calculation with very high precision, given that $95 \%$ of coils hit the precision range of $\pm 10 \%$ in the first three stands. This result outperforms references of best models in literature. For $\mathrm{Nb}$ microalloyed steels the hit rate drops to $89 \%$ in $\mathrm{FI}$ and to $65 \%$ in $\mathrm{F} 4$. In the rear stands the force predictability decreased significantly, likely due to factors such as strain hardening of austenite in the absence of recrystallization and to bending forces applied. 
Analyses of MFS behavior together with microstructure evolution indicated that softening and recrystallization phenomena affect the MFS in a nonlinear way, thus limiting the power of linear regressions to correct MFS. For example, CMn steels recrystallize after every deformation pass, at least partially, while microalloyed steels hardens increasingly. Then, an appropriate microstructure model could be coupled to the Schultz's model aiming at improving its performance in the rear stands.

\section{REFERENCES}

I Ginzburg VG. Steel rolling technology: theory and practice. New York: Marcel Dekker; 1989. 79 I p.

2 Gorni AA, Silva MRS. Comparação entre os modelos para o cálculo de carga na laminação a quente industrial. Tecnologica em Metalurgia, Materiais e Mineração. 2012;9(3):197-203.

3 Sims RB. The calculation of roll force and torque in hot rolling mills. Proceedings - Institution of Mechanical Engineers. 1954;168(I):191-214.

4 Maccagno TM, Jonas JJ, Hodgson PD. Spreadsheet for modelling of grain size evolution during rod rolling. ISIJ International. 1996;36(6):720-728.

5 Siciliano F. Mathematical modeling of the hot strip rolling of $\mathrm{Nb}$ microalloyed steels [thesis]. Montreal: McGill University; 1999.

6 Moon CH, Park HD. Integrated on-line model for the prediction of roll force and temperature in thick plate rolling. In: Proceedings of the Steel Rolling 2006: 9th International \& 4th European Conferences; 2006 June; Paris. Paris: Association Technique de la Siderurgie Française.

7 Barbosa JV, Giacomin CN, Santos AA, Maia GA. Análise comparativa da resistência à deformação a quente de aços de alta resistência em condições industriais. In: Anais do $55^{\circ}$ Seminário de Laminação e Conformação de Metais: ABM Week; 2018 Out 2-4; São Paulo, SP. São Paulo: ABM; 2018.

8 Fonseca NM, Santos AA, Resende BA, Giacomin CN. Modelo matemático para cálculo da carga de laminação de chapas grossas processadas por resfriamento acelerado. In: Anais do $49^{\circ}$ Seminário de Laminação: Processos e Produtos Laminados e Revestidos; 2012 Out 22-25; Vila Velha, ES. São Paulo: ABM; 2012.

9 Schultz RG, Smith AW Jr. Determination of a mathematical model for rolling mill control. Iron and Steel Engineer. 1965;80:127-133.

IO Siciliano F, Poliak El. Modeling of the resistance to hot deformation and the effects of microalloying in high-Al steels under industrial conditions. Materials Science Forum. 2005; I I (I5): 195-202.

I I Uranga P, Isasti N, Rodríguez-lbabe JM, Stalheim DG, Kendrick V, Frye B, et al. Optimized cost effective production of structural hot rolled CSP coils through proper austenite conditioning. In: AISTech 20 I7: Proceedings of the Iron \& Steel Technology Conference; 2017 May 8-II; Nashville, U.S.A. Warrendale: Association for Iron \& Steel Technology; 2017.

12 Dias ED, Castro JA, Araújo JO, Xavier CR, Sampaio AP. Análise comparativa de cargas de laminação a quente industriais com as obtidas através de modelamento matemático. Tecnologica em Metalurgia, Materiais e Mineração. 2019;16(3):325-333.

13 Stalheim DG. Recrystallization behaviors in the production of structural steels. In: Anais do Seminário de Laminação: Processos e Produtos Laminados e Revestidos: ABM Week; 2015 August 17-21; Rio de Janeiro, RJ. São Paulo: ABM; 2015 .

Received: 17 Out. 2019

Accepted: 23 Mar. 2020 